\title{
Effect of Acetazolamide on Cerebral Blood Flow and Cerebral Metabolic Rate for Oxygen
}

\author{
Sissel Vorstrup, Leif Henriksen, and Olaf B. Paulson \\ Department of Neurology, Rigshospitalet, University Hospital, \\ Copenhagen, 2100 Denmark
}

bstract. The aim of this study was to evaluate the effect of acetazolamide on cerebral blood flow (CBF) and cerebral metabolic rate for oxygen $\left(\mathrm{CMRO}_{2}\right)$. $\mathrm{CBF}$, arterial and jugular venous partial $\mathrm{O}_{2}$ pressure, partial $\mathrm{CO}_{2}$ pressure, $\mathrm{pH}$, and $\mathrm{O}_{2}$ saturation percentage were measured in six patients before and 3 and 20 minutes after intravenous administration of $1 \mathrm{~g}$ of acetazolamide. CBF was measured by the intracarotid ${ }^{133}$ xenon injection technique. In addition, changes in CBF were estimated from the arteriovenous oxygen content difference. CBF increased in all patients after acetazolamide, by $\sim 55$ and $70 \%$ after 3 and $20 \mathrm{~min}$, respectively. The CBF changes were of the same order whether calculated from the ${ }^{133} \mathrm{Xe}$ clearance or from the arteriovenous oxygen differences $(\mathrm{A}-\mathrm{V}) \mathrm{O}_{2} . \mathrm{CMRO}_{2}$, calculated from (A $-\mathrm{V}) \mathrm{O}_{2}$ differences and $\mathrm{CBF}$, remained constant. Except for an increase in the venous oxygen saturation, the blood gases remained constant.

Acetazolamide, in a dose sufficient to inhibit the erythrocyte carbonic anhydrase (EC 4.2.1.1), thus induced a rapid and marked increase in $\mathrm{CBF}$, leaving $\mathrm{CMRO}_{2}$ unchanged. This effect of acetazolamide on CBF is probably explained by a decrease in brain pH rather than by brain tissue hypoxia due to inhibition of oxygen unloading in the brain capillaries.

\section{Introduction}

Acetazolamide (Diamox; Lederle Laboratories, Div. American Cyanamid Co., Wayne, NJ), a selective inhibitor of carbonic anhydrase (EC 4.2.1.1), has been shown to induce a rapid increase in cerebral blood flow $(\mathrm{CBF})^{1}(1,2)$. After intravenous administration of a dose $>10 \mathrm{mg} / \mathrm{kg}$ in man, full physiological

Received for publication 5 December 1983 and in revised form 11 July 1984.

J. Clin. Invest.

(c) The American Society for Clinical Investigation, Inc.

$0021-9738 / 84 / 11 / 1634 / 06 \quad \$ 1.00$

Volume 74, November 1984, 1634-1639 inhibition of carbonic anhydrase activity in most tissues is achieved. This occurs within $1 \mathrm{~min}$ in the erythrocyte (3) but is somewhat slower in the brain tissues because of the retarded passage of the drug across the blood-brain barrier (4). The effect upon CBF has been shown to agree well with the locally induced changes of $\mathrm{pH}$ in the extracellular fluid compartment and, possibly, the intracellular compartment $(5,6)$. Some investigators looked for but could not demonstrate an additional hypoxic effect caused by inhibition of the Bohr effect in the microcirculation (7). Since the 1960 study of Posner and Plum (1), in which both CBF and cerebral metabolic rate of oxygen $\left(\mathrm{CMRO}_{2}\right)$ were measured and $\mathrm{CMRO}_{2}$ was found to remain constant, only one further study has tried to measure both of these variables (8). In that study, on adult rhesus monkeys, the results were interpreted to indicate that acetazolamide induced hypoxia of the brain tissue and consequently decreased $\mathrm{CMRO}_{2}$, an effect presumed to occur by interference with oxygen unloading in brain capillaries. It was concluded that this mechanism, together with an increase in the arterial $\mathrm{CO}_{2}$ tension $\left(\mathrm{PaCO}_{2}\right)$, explained the observed increase in $\mathrm{CBF}$ after acetazolamide administration.

As acetazolamide is used as an investigative tool in CBFstudies and also for long-term treatment of several diseases (e.g., glaucoma, pseudotumor cerebri), the mechanism behind the CBF effect is of major physiological and pathophysiological interest. We therefore reinvestigated $\mathrm{CBF}$ and $\mathrm{CMRO}_{2}$ in a series patients before and after an intravenous injection of $1 \mathrm{~g}$ of acetazolamide.

\section{Methods}

CBF studies were performed in six patients in whom regulation of the cerebral circulation was considered normal. The measurements were performed in conjunction with cerebral angiography. The diagnoses in these patients were epilepsy of unknown origin (1), small intracranial tumor (4), and dementia (1). The computerized tomography diagnosis

1. Abbreviations used in this paper: $(\mathrm{A}-\mathrm{V}) \mathrm{O}_{2}$, arteriovenous oxygen content difference; $\mathrm{CBF}$, cerebral blood flow; $\mathrm{CMRO}_{2}$, cerebral metabolic rate for oxygen; $\mathrm{O}_{2}$ sat $\%$, oxygen saturation percentage; $\mathrm{O}_{2}$ sat\%a and $\mathrm{O}_{2} \mathrm{sat} \% \mathrm{v}$, arterial and venous oxygen saturation percentages, respectively; $\mathrm{PCO}_{2}$, carbon dioxide tension; $\mathrm{PaCO}_{2}$ and $\mathrm{PvCO}_{2}$, arterial and venous carbon dioxide tensions, respectively; $\mathrm{PO}_{2}$, oxygen tension. 
in the two tumor cases was confirmed by the angiograms, which showed slight displacement of the vessels. In the remaining patients the angiograms were normal. The mean age of the patients (four men and two women) was $42 \mathrm{yr}$ (range from 16 to $72 \mathrm{yr}$ ).

Under local anesthesia and by the Seldinger technique, percutaneous puncture of the internal jugular vein and the carotid artery was performed and small polyethylene catheters were introduced (external diameters 1.60 and $1.25 \mathrm{~mm}$, respectively). The venous puncture was usually performed contralateral to the carotid artery appropriate for the angiogram. The tip of the jugular catheter was placed in the superior bulb of the jugular vein; correct positioning of this catheter was confirmed by the patient's hearing a rushing sound on the ipsilateral side when the catheter was flushed with saline. The tip of the carotid catheter was placed below the siphon. The correct position was ascertained by noting a discoloration confined to the superciliary region supplied by the internal carotid artery after a rapid injection of saline or Evans blue (T-1824). Both catheters were used for collection of blood samples after each CBF measurement. The arterial catheter was used for measurement of CBF and later for angiography. $10 \mathrm{~min}$ after the introduction of the catheters, $\mathrm{CBF}$ was measured and arterial and venous blood gases were sampled concomitantly. This procedure was repeated 3 and $20 \mathrm{~min}$ after a 1 -min intravenous infusion of $1 \mathrm{~g}$ of acetazolamide.

CBF was measured by the intra-arterial ${ }^{133}$ xenon injection technique $(9,10)$. The wash-out of isotope after a bolus injection of ${ }^{133}$ xenon dissolved in $1.5-2 \mathrm{ml}$ isotonic saline was followed by 16 parallel scintillation detectors placed externally over the ipsilateral hemisphere. Mean CBF values were calculated from the sum of the counts from all 16 detectors.

$\mathrm{CBF}_{\text {init }}$ was calculated from the initial part (first 1-2 min) of the logarithmically recorded clearance curve by the formula $\mathrm{CBF}_{\text {init }}=\lambda_{\mathrm{g}}$ $\times 2.3 \times D_{\text {init }} \times 100 \mathrm{ml} / 100 \mathrm{~g}$ per min, where $\lambda_{g}$ is the tissue to blood partition coefficient for gray matter, $0.87 \mathrm{ml} / \mathrm{g}, 2.3$ is the conversion factor from base 10 to the natural logarithm, $D_{\text {init }}$ is the value of the initial slope in units of decades per minute, and 100 is the factor for calculating flow per $100 \mathrm{~g}$ of tissue. If necessary, the flow values were corrected for remaining activity from previous ${ }^{133}$ xenon injections. $\mathrm{CBF}_{\text {init }}$ is an approximation of flow in gray matter. Usually the decay of the clearance curve is essentially monoexponential for the first 1-2 min and the slower clearance components first become apparent somewhat later.

CBF was also calculated by the height over area method by use of the linear clearance curve. $\mathrm{CBF}_{10}$ was the value obtained when the curve was followed for 10 minutes, whereas $\mathrm{CBF}_{10 \%}$ was obtained by following the curve until the height reached a value of $10 \%$ of the initial height (Fig. 1). These calculations were performed for the CBF measurement made before and 20 min after acetazolamide administration (by which time steady state was resumed). Calculations of $\mathrm{CBF}_{10}$ and $\mathrm{CBF}_{10 \%}$ were performed according to the formula $\mathrm{CBF}_{\mathrm{t}}$ $=\bar{\lambda} \times\left(H_{0}-H_{t} / A_{0}-A_{\mathrm{t}}\right) \times 100 \mathrm{ml} / 100 \mathrm{~g}$ per min, where $\bar{\lambda}$ is the average tissue-to-blood partition coefficient for brain, set to $1.25 \mathrm{ml} / \mathrm{g}$, $H_{0}$ is the initial height of the clearance curve, $H_{\mathrm{t}}$ is the height at time $\mathrm{t}$, and $A_{0}-A_{1}$ is the area under the clearance curve during the time interval $t$. These calculations were performed manually and corrected for remaining activity. $t$ was either $10 \mathrm{~min}\left(\right.$ for $\mathrm{CBF}_{10}$ ) or the time at which the height of the clearance curve had decreased to $10 \%$ of its initial height (for $\mathrm{CBF}_{10 \%}$ ). $C B F_{10}$ and $\mathrm{CBF}_{10 \%}$ approximate the average flow in the hemisphere. The use of a fixed $\lambda$-value was felt to be justified, as this parameter will not influence the relative changes of $\mathrm{CBF}$ in the single patient.

Changes in $\mathrm{CBF}$ were also estimated from the arteriovenous oxygen content difference $\left[(\mathrm{A}-\mathrm{V}) \mathrm{O}_{2}\right]$, i.e., $\mathrm{CBF}$ is calculated as $1 /(\mathrm{A}-\mathrm{V}) \mathrm{O}_{2}$

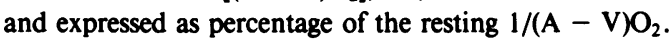

$\mathrm{pH}$, carbon dioxide tension $\left(\mathrm{PCO}_{2}\right)$ and oxygen tension $\left(\mathrm{PO}_{2}\right)$, were determined several minutes after blood sampling when carbon dioxidebicarbonate equilibrium had been reached by use of conventional electrodes (Acid-Base Laboratory 3, Radiometer, Copenhagen). Oxygen saturation percentage $\left(\mathrm{O}_{2}\right.$ sat\%) was determined spectrophotometrically (OSM2, Hemoximeter; Radiometer, Copenhagen), a method not influenced by $\mathrm{pH}$ and $\mathrm{PCO}_{2}$ shifts.
Arbitrary units

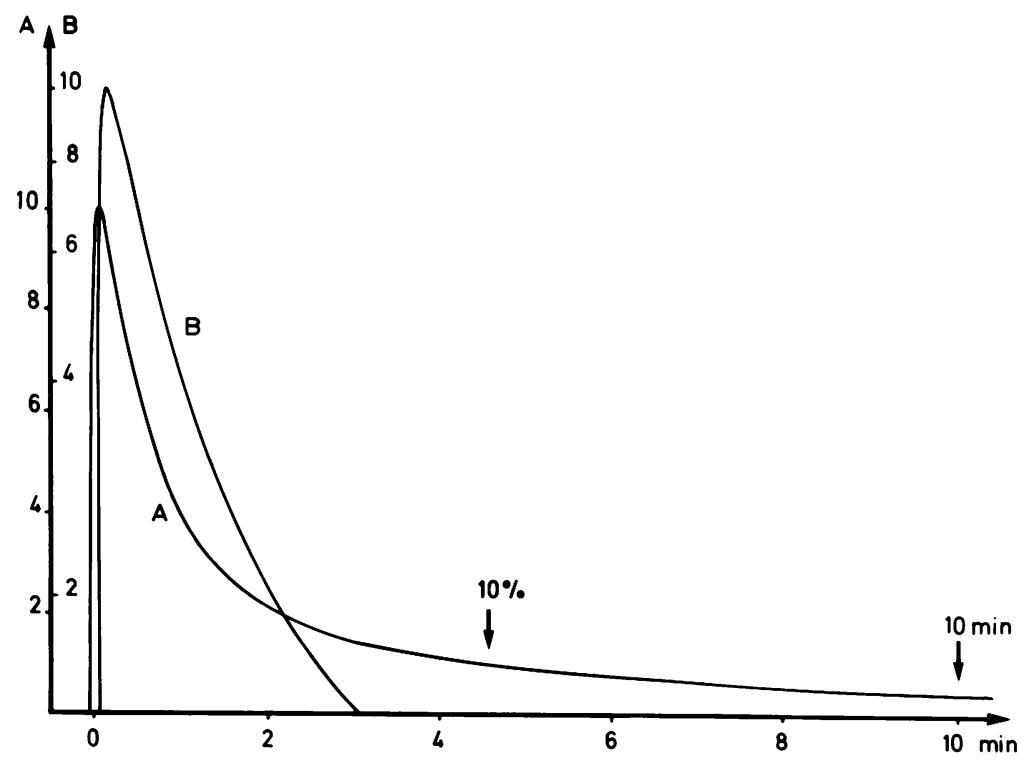

Figure 1. The linear $(A)$ and semilogarithmic $(B)$ clearance curves after an intracarotid injection of ${ }^{133}$ xenon. CBF was calculated using the height over area method following the linear curve for either 10 minutes $\left(\mathrm{CBF}_{10}\right)$ or until the height reached a value of $10 \%$ of the initial height $\left(\mathrm{CBF}_{10 \%}\right) . \mathrm{CBF}_{\text {init }}$ was calculated from the initial part (1-2 $\mathrm{min}$ ) of the semilogarithmic curve. 


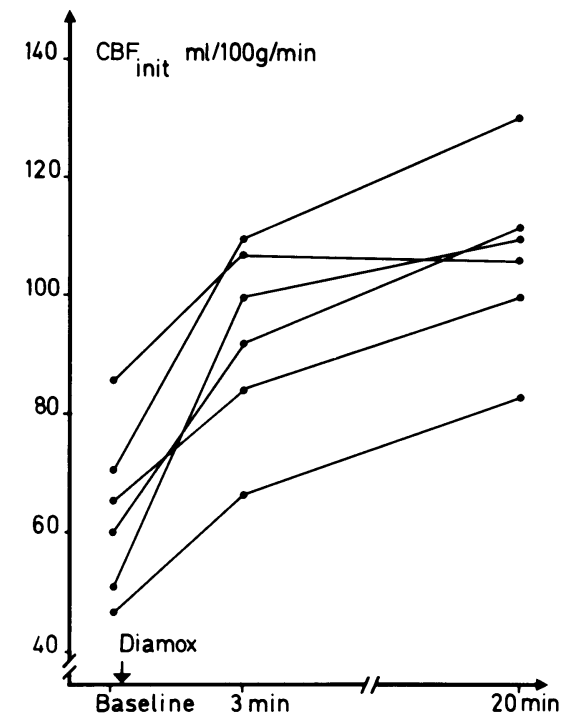

Figure 2. Individual changes in CBF after acetazolamide (Diamox) administration. $\mathrm{CBF}_{\text {init }}$ was calculated from the initial part of the ${ }^{133}$ xenon clearance curves.

The arteriovenous oxygen difference was calculated from the $\mathrm{O}_{2}$ sat $\%$ difference in arterial and venous blood $\left(\mathrm{O}_{2}\right.$ sat\%a and $\mathrm{O}_{2}$ sat\%v, respectively), and the hemoglobin concentration $\mathrm{Hb}$ in millimoles/100 milliliters, assuming an oxygen binding capacity of $21.58 \mathrm{ml} / \mathrm{mmol}$ hemoglobin: $(\mathrm{A}-\mathrm{V}) \mathrm{O}_{2}=\left[\left(\mathrm{O}_{2}\right.\right.$ sat\%a $-\mathrm{O}_{2}$ sat\%v $\left.) / 100\right] \times \mathrm{Hb} \times 21.58$ $\mathrm{ml} / 100 \mathrm{ml}$.
The small arteriovenous changes in dissolved $\mathrm{O}_{2}$ are negligible at normal arterial $\mathrm{O}_{2}$ tension levels and were therefore not included in the calculations.

$\mathrm{CMRO}_{2}$ was calculated using $\mathrm{CBF}_{\text {init }}, \mathrm{CBF}_{10}$, and $\mathrm{CBF}_{10 \%}$ according to the formula $\mathrm{CMRO}_{2}=(\mathrm{A}-\mathrm{V}) \mathrm{O}_{2} \times \mathrm{CBF} \mathrm{ml} / 100 \mathrm{~g}$ per min.

Statistics. Comparisons between duplicate measurements were performed by paired $t$ test. When three measurements were analyzed a multiple range test (Newman-Keuls test) was applied (11). A $P$ value $<0.05$ was used for statistical significance.

\section{Results}

Effect of acetazolamide on CBF. CBF increased in all patients after administration of acetazolamide. The individual changes in $\mathrm{CBF}_{\text {init }}$ are presented in Fig. 2. The increase was $\sim 55 \% 3$ min after administration and had further increased to $\sim 70 \%$ 17 min later. At this time the increase in CBF was evaluated by all four modes of calculation (Table I, Fig. 3). Each showed an increase of the same order varying between 57 and $75 \%$, lowest for $\mathrm{CBF}_{10}$ and highest for $\mathrm{CBF}_{10 \%}$.

Effect of acetazolamide on $\mathrm{CMRO}_{2} \cdot \mathrm{CMRO}_{2}$ as calculated from either $\mathrm{CBF}, \mathrm{CBF}_{10 \%}$, or $\mathrm{CBF}_{10}$ showed no statistically significant change from the resting metabolic state after acetazolamide administration. $\mathrm{CMRO}_{2}$ as calculated from $\mathrm{CBF}_{\text {init }}$ and $\mathrm{CBF}_{10 \%}$ showed a slight increase, averaging $8 \%$ at $20 \mathrm{~min}$ after acetazolamide injection, whereas $\mathrm{CMRO}_{2}$ as calculated from $\mathrm{CBF}_{10}$ yielded a decrease of $8 \%$.

Effect on blood gases. $\mathrm{PaCO}_{2}$, venous $\mathrm{CO}_{2}$ tension $\left(\mathrm{P}_{\mathrm{v}} \mathrm{CO}_{2}\right)$, and the arterial and venous $\mathrm{pH}$ showed no significant changes throughout the study. Also after acetazolamide administration,

Table I. Effect of Acetazolamide on $\mathrm{CBF}$ and $\mathrm{CMRO}_{2}$

\begin{tabular}{|c|c|c|c|c|c|}
\hline & \multicolumn{3}{|l|}{ Time } & \multirow[b]{2}{*}{$P$} & \multirow[b]{2}{*}{ No. } \\
\hline & Baseline* & $3 \min \ddagger$ & $20 \min \ddagger$ & & \\
\hline $\mathrm{CBF}_{\text {init }}(\mathrm{ml} / 100 \mathrm{~g}$ per min $)$ & $64 \pm 14$ & $95 \pm 12$ & $108 \pm 13$ & $<0.001 \S$ & 6 \\
\hline $\mathrm{CBF}_{10}(\mathrm{ml} / 100 \mathrm{~g}$ per min $)$ & $51 \pm 5$ & & $80 \pm 17$ & $<0.005$ & 5 \\
\hline $\mathrm{CBF}_{10 \%}(\mathrm{ml} / 100 \mathrm{~g}$ per min $)$ & $56 \pm 6$ & & $98 \pm 6$ & $<0.001$ & 5 \\
\hline $\mathrm{CMRO}_{2 \text { init }}(\mathrm{ml} / 100 \mathrm{~g}$ per min $)$ & $3.81 \pm 5.30$ & $3.91 \pm 0.15$ & $4.12 \pm 0.34$ & NS & 6 \\
\hline $\mathrm{CMRO}_{210}(\mathrm{ml} / 100 \mathrm{~g}$ per min $)$ & $3.09 \pm 0.85$ & & $2.82 \pm 0.62$ & NS & 5 \\
\hline $\mathrm{CMRO}_{210 \%}(\mathrm{ml} / 100 \mathrm{~g}$ per min $)$ & $3.54 \pm 0.88$ & & $3.80 \pm 0.77$ & NS & 5 \\
\hline $\mathrm{CBF}_{\text {init }}(\%$ change $)$ & & $53 \pm 24$ & $73 \pm 31$ & $\begin{array}{l}<0.005 \S \\
<0.005^{\prime \prime}\end{array}$ & 6 \\
\hline $\mathrm{CBF}_{10}(\%$ change $)$ & & & $57 \pm 33$ & $<0.001$ & 5 \\
\hline $\mathrm{CBF}_{10 \%}(\%$ change $)$ & & & $75 \pm 16$ & $<0.001$ & \\
\hline$\left[(\mathrm{A}-\mathrm{V}) \mathrm{O}_{2} \text { sat } \%\right]^{-1}(\%$ change $)$ & & $51 \pm 16$ & $61 \pm 21$ & $\begin{array}{l}<0.01 \S \\
<0.0111\end{array}$ & 6 \\
\hline $\mathrm{CMRO}_{2}$ init $(\%$ change $)$ & & $3.1 \pm 4.5$ & $8.6 \pm 8.5$ & NS & 6 \\
\hline $\mathrm{CMRO}_{210}(\%$ change $)$ & & & $-8.2 \pm 5.2$ & NS & 5 \\
\hline $\mathrm{CMRO}_{2}{ }_{10 \%}(\%$ change $)$ & & & $7.8 \pm 21.1$ & NS & 5 \\
\hline
\end{tabular}

NS, not significant. * Baseline values are given as mean \pm SD. $¥$ Values are given as mean $\pm \Delta S D$, where $\Delta S D$ indicates the SD of change from baseline. $\$ 20 \mathrm{~min}$ vs. baseline. " $3 \mathrm{~min}$ vs. baseline. 


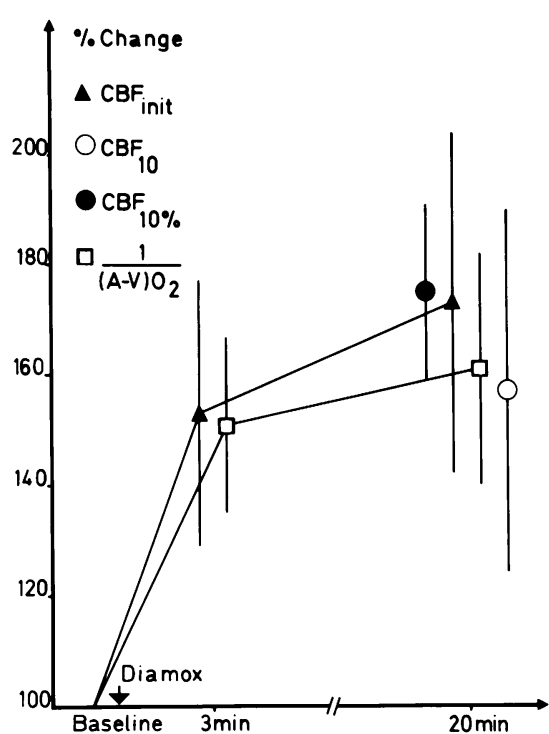

Figure 3. Influence of acetazolamide (Diamox) on CBF. The changes were calculated from the ${ }^{133}$ xenon clearance curves, yielding $\mathrm{CBF}_{\text {init }}$, $\mathrm{CBF}_{10}$, and $\mathrm{CBF}_{10 \%}$. [1/(A-V)O $\left.\mathrm{O}_{2}\right]$ indicates the estimated change in $\mathrm{CBF}$ by the arteriovenous oxygen content difference method. Each point represents the mean value, and the vertical lines indicate 1 $\Delta \mathrm{SD}$, where $\Delta \mathrm{SD}$ is the $\mathrm{SD}$ of change from baseline.

the $\mathrm{O}_{2}$ sat $\%$ a remained constant, whereas the $\mathrm{O}_{2}$ sat $\% \mathrm{v}$ increased (significant at $P<0.005$ ). This increase corresponded to an increase of the venous oxygen content averaging 17 and $21 \%$ at 3 and $20 \mathrm{~min}$ after injection (Table II, Fig. 4).

\section{Discussion}

In the present study, the changes in CBF after acetazolamide administration were evaluated by four different modes of

Table II. Effect of Acetazolamide on Blood Gases

\begin{tabular}{ccccc}
\hline & \multicolumn{1}{l}{ Time } & & \\
\cline { 2 - 3 } & Rest* & $3 \mathrm{~min} \ddagger$ & $20 \mathrm{~min} \ddagger$ & $P$ \\
\hline $\mathrm{PaCO}_{2}$ & & & & \\
$(k P a) \S$ & $5.36 \pm 0.22$ & $5.51 \pm 0.16$ & $5.47 \pm 0.32$ & $\mathrm{NS}$ \\
$\mathrm{PvCO}_{2}$ & & & & \\
$(k P a)$ & $6.57 \pm 0.53$ & $6.30 \pm 0.49$ & $6.10 \pm 0.41$ & $\mathrm{NS}$ \\
$\mathrm{pH}_{\mathrm{a}}$ & $7.40 \pm 0.03$ & $7.39 \pm 0.01$ & $7.39 \pm 0.02$ & $\mathrm{NS}$ \\
$\mathrm{pH}_{\mathrm{v}}$ & $7.35 \pm 0.03$ & $7.37 \pm 0.02$ & $7.36 \pm 0.02$ & $\mathrm{NS}$ \\
$\mathrm{O}_{2}$ sat\%a & $96 \pm 2$ & $95 \pm 3$ & $97 \pm 2$ & $\mathrm{NS}$ \\
$\mathrm{O}_{2}$ sat\%v & $63 \pm 6$ & $74 \pm 4$ & $77 \pm 5$ & $<0.01^{\prime \prime}$
\end{tabular}

$\mathrm{pH}_{\mathrm{a}}$, arterial $\mathrm{pH} ; \mathrm{pH}_{\mathrm{v}}$, venous $\mathrm{pH}$. NS, not significant.

* Baseline to values are given as mean \pm SD.

$¥$ Values are given as mean $\pm \Delta S D$, where $\Delta S D$ indicates the $S D$ of change from baseline.

$\S \mathrm{kPa}, \mathrm{kPascal}$.

I" $3 \mathrm{~min}$ vs. baseline, $20 \mathrm{~min}$ vs. baseline.

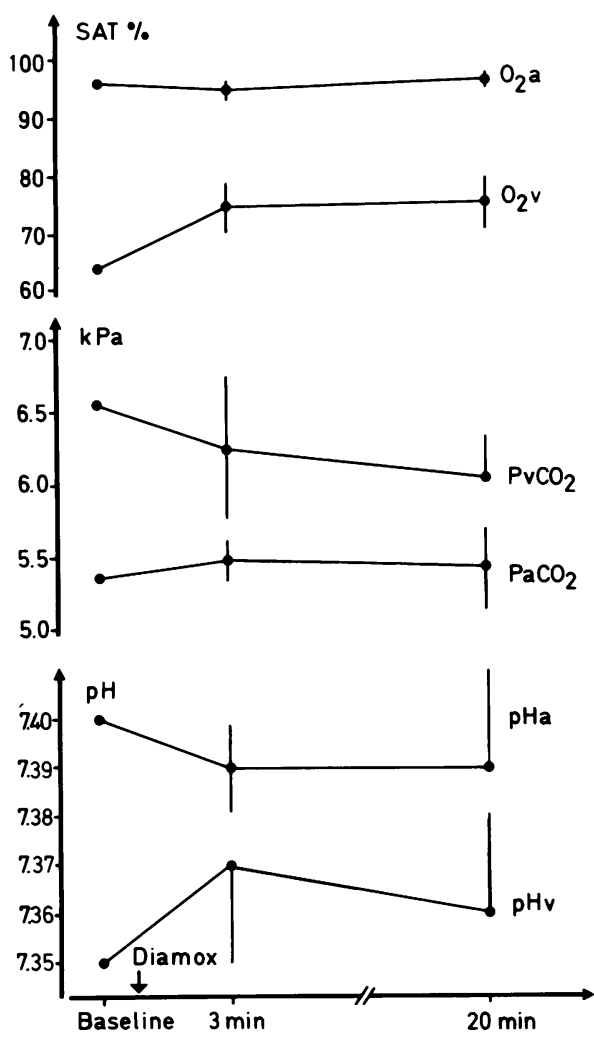

Figure 4. Influence of acetazolamide (Diamox) on blood gases in six patients. Each point represents the mean value, and the vertical lines indicate $\triangle \mathrm{SD}$, i.e., the SD of change from baseline. $\mathrm{kPa}, \mathrm{kPascal}$.

calculation. $\mathrm{CBF}_{\text {init }}$ is an approximation of the flow in gray substance, underestimating this by 20-30\%, independent of the flow level (10). $\mathrm{CBF}_{10}$ is an approximation of average brain blood flow, a value that overestimates the true value by $\sim 15 \%$, because the approximation disregards the tail part of the clearance curve (after $10 \mathrm{~min}$ ), which represents predominantly the slowest clearance components (10).

If flow increases, the clearance increases as well, and more of the tail will now be included in the first 10 -min period that is used for the flow calculation. Consequently, overestimation of the true average flow value will be less pronounced, and the average flow increase will be underestimated. To circumvent this limitation, calculations could be performed by following the clearance curves to a certain degree of desaturation, e.g., a value of $10 \%$ of the initial height. Thus a more constant fraction of the tail part of the clearance curve would be excluded from the calculations. However, if the flow increase is confined mostly to the compartments with rapid clearance (gray matter), this mode of calculation will disregard the slower perfused compartments with a more constant clearance, and consequently overestimate the average flow increase. Similar considerations apply to the calculation of $\mathrm{CBF}_{\text {init }}$ if these values are considered to be representative of the average cerebral flow 
increase, which is the case when $\mathrm{CMRO}_{2}$ is calculated from $\mathrm{CBF}_{\text {init }}$.

After acetazolamide administration we observed a slight increase in $\mathrm{CMRO}_{2}$ as calculated from $\mathrm{CBF}_{\text {init }}$ and $\mathrm{CBF}_{10 \%}$, whereas $\mathrm{CMRO}_{2}$ as calculated from $\mathrm{CBF}_{10}$ decreased slightly. These observations agree well with the assumption of a truly unchanged oxidative metabolism in the brain tissue and also with the considerations described above on over- and underestimation of the flow changes.

The arteriovenous oxygen content difference method yielded flow increases of the same order as those obtained with the ${ }^{133}$ xenon clearance method. The $\mathrm{CMRO}_{2}$ results further indicate the validity of the arteriovenous oxygen content difference method for measuring flow changes after acetazolamide application.

The range of increase in CBF (53-75\%) observed in the present study agrees well with the findings in most other studies that use a variety of direct and indirect CBF techniques and acetazolamide doses sufficient to achieve complete inhibition of erythrocyte carbonic anhydrase $(1,2,5,7)$. Only in one study was an increase of $<50 \%$ reported (8). By the use of smaller doses of acetazolamide $(<10 \mathrm{mg} / \mathrm{kg})$ the inhibition of the carbonic anhydrase in the erythrocyte will be incomplete. With a dose of $0.5 \mathrm{~g}$ to patients, flow has been shown to increase insignificantly during the first $5 \mathrm{~min}$ (12), but later flow may increase by $30 \%$ (13).

The exact mechanism by which acetazolamide increases CBF has not been clarified. In an extensive review (14) it was stated that the only known effect of acetazolamide was to inhibit carbonic anhydrase. It has been shown that inhibition of the enzyme, e.g., in the erythrocytes, kidney, or pancreas, affects the ionic exchanges of $\mathrm{HCO}_{3}^{-}$. In the brain where the enzyme is localized in the glial cells and in the choroid plexus (15), both the effects of the enzyme and its inhibition are unclear. Because of the retarded passage of acetazolamide across the blood-brain barrier it may be assumed that the rapid CBF changes are not caused by inhibition of intracerebral carbonic anhydrase. It has been suggested that acetazolamide, by delaying the conversion of $\mathrm{H}_{2} \mathrm{CO}_{2} \rightleftharpoons \mathrm{H}^{+}+\mathrm{HCO}_{3}^{-}$by carbonic anhydrase inhibition in the erythrocyte, would prevent acidification and oxygen unloading in the capillaries, i.e., the Bohr effect. If flow were constant, this would lead to a decrease in cerebral tissue $\mathrm{PO}_{2}$. However, measurements have shown a significant increase in $\mathrm{PO}_{2}(7,16)$ brought about by the CBF increase. In a recent study, Laux and Raichle (8) studied CBF and $\mathrm{CMRO}_{2}$ with the intra-arterial $\left({ }^{15} \mathrm{O}\right) \mathrm{H}_{2} \mathrm{O}$ and the $\left({ }^{15} \mathrm{O}\right) \mathrm{O}_{2}$ clearance technique in monkeys. They found a moderate increase of $\mathrm{CBF}$ which averaged $29.2 \%$, and a $\mathrm{CMRO}_{2}$ reduction of $\sim 32 \%$ occurring within minutes of acetazolamide administration. The data were interpreted as suggesting an interference with oxygen unloading in the capillary bed, causing tissue hypoxia. This effect, together with an observed increase in $\mathrm{PaCO}_{2}$, was thought to explain the increase in CBF. In the present study, we found an increase in CBF and an unchanged
$\mathrm{CMRO}_{2}$ after acetazolamide administration. Similarly, Posner and Plum found an unchanged $\mathrm{CMRO}_{2}$ (1). Thus, the assumption of a reduced oxygen supply to the brain resulting in a reduced oxidative metabolism seems unlikely.

$\mathrm{PaCO}_{2}$ after acetazolamide has been reported to either increase or remain unchanged. If complete physiological inhibition of carbonic anhydrase in the erythrocytes is suddenly induced an in vivo disequilibrium in the $\mathrm{CO}_{2}$ system results, leading to a decrease in alveolar $\mathrm{PCO}_{2}$ and pulmonary capillary $\mathrm{PCO}_{2}$. However, a continuous increase in $\mathrm{PCO}_{2}$ takes place in the arterial blood as it approaches the tissues. As acetazolamide increases total blood carbonic acid, analyses of arterial blood samples will tend to overestimate the in vivo $\mathrm{pCO}_{2}$ as equilibrium is still further approached after sampling. We observed a small but statistically insignificant increase in $\mathrm{PaCO}_{2}$, which agrees with the theoretical considerations and corresponds to the findings in man reported by Ehrenreich et al. (2), who used a similar dose of acetazolamide.

After intravenous administration of acetazolamide a rapid decrease is induced in the $\mathrm{pH}$ of cerebrospinal fluid on the surface of dog brain, despite maintenance of a constant $\mathrm{PaCO}_{2}$ (5). Also, an increased $\mathrm{CO}_{2}$ tension on the cerebral cortex (17) and an intracellular carbonic acidosis with a decrease of brain tissue lactate and pyruvate after acetazolamide administration correspond to the observations in tissue acidosis produced by hypercapnia (18). These results seem to indicate that the effect of acetazolamide on CBF is mediated via inhibition of carbonic anhydrase in the erythrocytes by impeding the removal of $\mathrm{CO}_{2}$ in the brain tissue by the blood stream.

Lately, Hauge and co-workers (19) suggested that acetazolamide might have a direct local vasodilator effect upon the cerebral arterioles, unrelated to its specific effect as a carbonic anhydrase inhibitor. In their study, the time course of the relative changes in internal carotid flow velocity after an intravenous dose of $500 \mathrm{mg}$ acetazolamide was followed by a pulsed ultrasound Doppler system in man. An increase in flow was already detected $2 \mathrm{~min}$ after the injection, reaching a maximum averaging $75 \%$ after $25 \mathrm{~min}$. This increase is more pronounced than that observed by other authors using different CBF methods $(12,13)$. In our opinion, neither the results from the study of Hauge et al. (19) nor those of others seem to justify such a hypothesis of another mechanism of action of acetazolamide.

In conclusion, our study confirms that acetazolamide induces a rapid increase in $\mathrm{CBF}$, and demonstrates that this occurs without concomitant changes in the $\mathrm{CMRO}_{2}$.

\section{Acknowledgments}

The authors are grateful to Glenna Skouboe and Bodil Kjær for their excellent technical assistance.

This study was supported by grants from the Danish Medical Research Council. 


\section{References}

1. Posner, J. B., and F. Plum. 1960. The toxic effects of carbon dioxide and acetazolamide in hepatic encephalopathy. $J$. Clin. Invest. 39:1246-1258.

2. Ehrenreich, D. L., R. A. Burns, R. W. Alman, and J. F. Fazekas. 1961. Influence of acetazolamide on cerebral blood flow. Arch. Neurol. 5:227-232.

3. Maren, T. H. 1977. Use of inhibitors in physiological studies of carbonic anhydrase. Am. J. Physiol. 232:F291-F297.

4. Roth, L. J., J. C. Schoolar, and C. F. Barlow. 1959. Sulfur-35 labelled acetazolamide in cat brain. J. Pharmacol. Exp. Ther. 125:128136.

5. Severinghaus, J. W., and S. Cotev. 1968. Carbonic acidosis and cerebral vasodilation after diamox. Scand. J. Clin. Lab. Invest. 1(Suppl. 102):E.

6. Heuser, D., J. Astrup, N. A. Lassen, and E. Betz. 1975. Brain carbonic acid acidosis after acetazolamide. Acta Physiol. Scand. 93:385390.

7. Cotev, S., J. Lee, and J. W. Severinghaus. 1968. The effects of acetazolamide on cerebral blood flow and cerebral tissue $\mathrm{PO}_{2}$. Anesthesiology. 29:471-477.

8. Laux, B. E., and M. E. Raichle. 1978. The effect of acetazolamide on cerebral blood flow and oxygen utilization in the rhesus monkey. J. Clin. Invest. 62:585-592.

9. Heedt-Rasmussen, K., E. Sveinsdottir, and N. A. Lassen. 1966. Regional cerebral blood flow in man determined by intra-arterial injection of radioactive inert gas. Circ. Res. 18:237-247.
10. Olesen, J., O. B. Paulson, and N. A. Lassen. 1971. Regional cerebral blood flow in man determined by the initial slope of the clearance of intra-arterially injected xenon-133. Stroke. 2:519-540.

11. Zar, J. H. 1974. Biostatistical Analysis. Prentice-Hall Inc., Englewood Cliffs, New Jersey. 151-155.

12. Friis, M. L., O. B. Paulson, and M. M. Hertz. 1980. Carbondioxide permeability of the blood-brain barrier in man. The effect of acetazolamide. Microvasc. Res. 20:71-80.

13. Gotoh, F., J. S. Meyer, and M. Tomita. 1966. Carbonic anhydrase inhibition and cerebral venous blood gases and ions in man. Arch. Intern. Med. 117:39-46.

14. Maren, T. H. 1967. Carbonic anhydrase: chemistry, physiology, and inhibition. Physiol. Rev. 47(4):595-781.

15. Giacobini, E. 1962. A cytochemical study of the localization of carbonic anhydrase in the nervous system. J. Neurochem. 9:169177.

16. Meyer, J. S., F. Gotoh, and Y. Tazaki. 1961. Inhibitory action of carbon dioxide and acetazolamide in seizure activity. Electroencephalogr. Clin. Neurophysiol. 13:762-775.

17. Brzezinski, J., A. Kjällquist, and B. K. Siesjö. 1967. Mean carbon dioxide tension in the brain after carbonic anhydrase inhibition. J. Physiol. (Lond.). 188:13-23.

18. Kjällquist, Å., M. Nardini, and B. K. Siesjö. 1969. The effect of acetazolamide upon tissue concentrations of bicarbonate, lactate, and pyruvate in the cat brain. Acta Physiol. Scand. 77:241-251.

19. Hauge, A., G. Nicolaysen, and M. Thoresen. 1983. Acute effects of acetazolamide on cerebral blood flow in man. Acta Physiol. Scand. 117:233-239. 